\title{
SOCIAL NETWORK ANALYSIS IN PARTICIPATORY ENVIRONMENTAL DECISION MAKING. THE CASE OF SPANISH WETLAND LA ALBUFERA.
}

\author{
Mónica García Melón* \\ INGENIO (Instituto mixto CSIC-UPV) \\ Universitat Politècnica de València \\ mgarciam@dpi.upv.es \\ Vicent Estruch Guitart \\ Depto. Economía y Ciencias Sociales \\ Universitat Politècnica de València \\ vestruch@esp.upv.es \\ Pablo Aragonés Beltrán \\ INGENIO (Instituto mixto CSIC-UPV) \\ Universitat Politècnica de València \\ aragones@dpi.upv.es
}

Beatriz Monterde Roca

beamonro@etsii.upv.es

\begin{abstract}
The aim of this paper is to analyze the influence of the stakeholders in a participatory decision making process. In the present work we have used Social Network Analysis to study the influences of the different stakeholders and the AHP technique to analyze the decision making process.

The results will be analyzed using two different models: the AHP model when considering that all the stakeholders have the same influence and the weighted-AHP model when considering the relative influence of each stakeholder using the weights assigned in the SNA analysis
\end{abstract}

\section{Introduction}

Shared responsibility for the protection of nature demands common solutions to existing problems. Environmental management decisions have been the cause of many debates and deep disagreements underlying the multifaceted nature of most environmental problems. Environmental management takes place at many levels (local communities, city, state, ...) and involves a large number of stakeholders (such as landowners, entrepreneurs, urban planners, farmers...) with conflicting interests (Regan et al., 2006). The complexity of environmental problems requires transparent and flexible decision-making processes that integrate different areas of knowledge and values (Reed, 2008). In order to reach a consensus-based solution all stakeholders should get involved in the decision process (García-Melon, 2011,Garcia-Melon 2012,Aragones-Beltran 2009).

The present work analyzes the influences and relationships between the stakeholders involved in a specific environmental problem, namely rice straw management in the Natural Park of La Albufera, Valencia (Spain). The case study includes different entities identified as being

\footnotetext{
* Corresponding author
} 
stakeholders over many years. Identifying the stakeholders is not within the scope of our study, but rather analyzing (and quantifying) which stakeholders have more influence on the decisionmaking process under study. This paper also describes the influences existing in the network of the decision-problem model in order to draw some general conclusions.

The research questions formulated in this study are: 1) How does the information flow operate within this network? based on the questions posed, i.e. who provides you with information regarding the problem and who requests information from you regarding this problem. Our aim is to determine which stakeholders are most frequently contacted by the other stakeholders and therefore have the ability to control the information flow. The study will also identify the stakeholders who request the most information. 2) Is SNA a useful tool for the purpose of estimating stakeholders' influence? 3) Can the results be used to assign weights or influences to stakeholders involved in a decision-making process?

\section{Stakeholder analysis}

The approach proposed for determining the power relations between the stakeholders involved in the decision problem falls within the field of information flow. The number of times that each stakeholder contacts other stakeholders will serve to determine which stakeholders are most frequently requested to provide information and therefore are more likely to influence the decision process

The resulting information network will then be analyzed from the perspective of Social Network Analysis to obtain the centrality of individual actors.

There are three approaches to calculate the centrality of a node: based on degree, on closeness, and on betweenness (Wasserman \&Faust, 2007). These three approaches describe the location of nodes "in terms of how close they are to the "center" of the action in a network"(Hanneman $\&$ Riddle, 2005). However, the definitions of what it means to be at the 'center' differ.

Because of the small number of actors involved in the decision-making problem under study, betweenness centrality has not been used as the contact paths between actors are very short. Therefore only degree and closeness centralities were used in the SNA model ${ }^{1}$

\footnotetext{
${ }^{1}$ Degree centrality:

Degree centrality is defined as the number of direct ties of an actor with the other actors in the network. The indices of centrality are based on the choices made; therefore, in directed networks, as in our case study, only out-degree (outgoing links) is considered, i.e. which actors each stakeholder involved in the process has had contacts with (Wasserman \&Faust, 2007). Out-degree is calculated as the sum of direct ties of an actor with the other actors in the network.

$$
C_{D}\left(n_{i}\right)=x_{i+}=\sum_{j=1} x_{i j}(e q .1)
$$
}

where

$X_{i j}$ is the number of direct ties of actor I with the other actors in the network

Closeness centrality

Closeness centrality indicates how close a node is to the other nodes in the network. Actors who have a high closeness index have many direct ties with several members of the network (Sedereviciute, 2010). The higher the closeness centrality of a node, the faster it is able to interact with the rest of the actors (Knoke \&Yang, 2008). The highest closeness occurs when all actors are at a distance of one step from the main actor (geodesic distances). Closeness is calculated as follows:

where

$$
C_{C}^{\prime}\left(n_{i}\right)=\frac{g-1}{\left[\sum_{j=1}^{g} d\left(n_{i}, n_{j}\right)\right]}
$$

$d(n i, n j)$ is the distance between actor $n i$ and actor $n j$

$g$. is the total number of actors in the network 


\section{Methodology proposed}

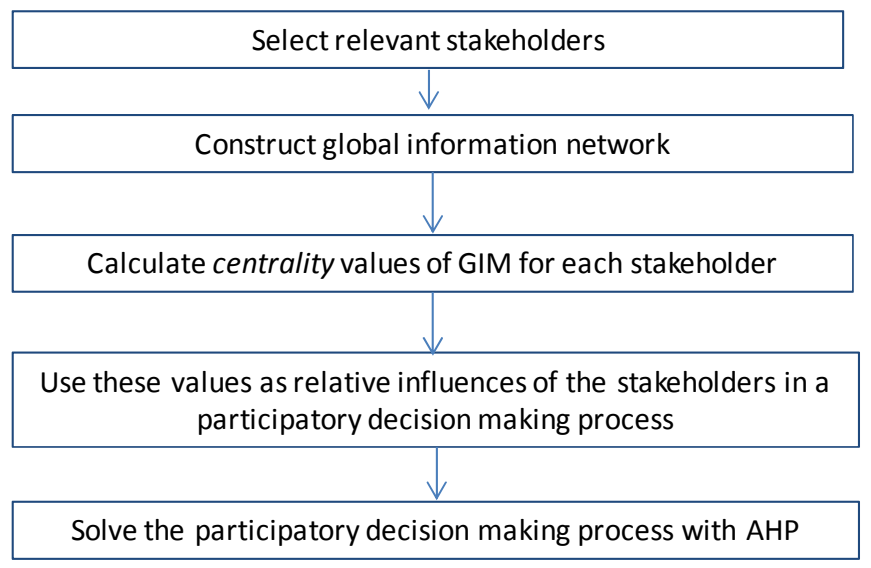

\section{Case study. Participatory management of La Albufera wetland, Spain}

\subsection{General overview / background}

The Albufera Natural Park, with a surface area of 21,000hectares, is located $9 \mathrm{~km}$ to the south of the city of Valencia (Fig.1). The park extends along the coastline between the new channel of the Turia river and the mountains of Cullera, and includes the Albufera lagoon and all surrounding rice fields until the Xúquer river

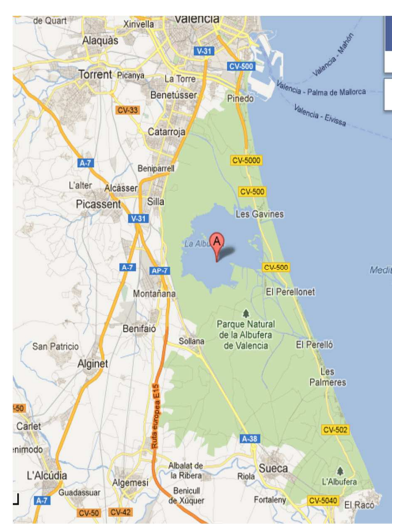

In this park, as in most Mediterranean wetlands, agricultural activities, particularly rice farming, have caused major changes in the original aquatic ecosystems, some of which are beneficial to a large community of water birds for which rice fields are an alternative habitat. Rice cultivation also allows the development of an interesting agro-aquatic ecosystem

Figure 1. Map of La Albufera.

The introduction of new straw management systems causes important environmental problems in wet years. Formerly rice straw was burnt, causing air pollution. Current agro-environmental regulations prohibit this practice, except under special conditions. If the fields do not dry out due to heavy autumn rains, tractors cannot remove the straw from the field or incorporate it to the soil. In waterlogged soil rice straw decomposes anaerobically generating toxic metabolites for aquatic organisms. Other straw management practices increase farming costs, shorten the hunting season or increase air pollution. 


\subsection{Selection of relevant stakeholders.}

There are many stakeholders with conflicting interests involved in the problem of rice straw management:

1.Technical Management Office of the Park

2.Regional Ministry for the Environment

3.Regional Ministry of Agriculture

4. Valencia City Council (Devesa-Albufera Service)

5.La Unio Farmers' Union

6.SEO Birdlife

7.La Albufera Fishermen's Association

8.Hunters Society

Of the eight stakeholders involved in the problem, one of them, Valencia City Council, is the owner of the lake and is therefore interested in keeping it in the best possible environmental conditions. Two other stakeholders are Regional Ministries: the Department of Agriculture, which is responsible for the development and management of environmental policies (and decides on which farming techniques to subsidize or ban) and the Department of Environment, which is responsible for environmental policies and sets the hunting seasons. Another stakeholder is the Management Office of the Park, which is responsible for monitoring the conditions and activities developed in the park. The other stakeholders are: a Farmers' Union, representing farmers, whose interest is reducing farming costs as much as possible, a representative of the Fishermen's Association, who are affected by the increasing mortality of fish due to rice-straw contamination, and a representative of SEO BirdLife, which is an association for environmental defense that is very popular in the area.

\subsection{Construction of the global information matrix (GIM)}

For the case study presented in this work we used two information networks, one consists of the active search for information and is built using the answers given by all stakeholders to the first question of the questionnaire.

Q1. Regarding the consequences of the different rice straw management methods, who do you ask for information? How often?

The second network is the passive search for information and is built using the answers given by all stakeholders to the second question of the questionnaire.

Q2. Regarding the consequences of the different rice straw management methods, who asks you for information? How often?

The answers to Questions 1 and 2 allowed us to determine the relationships of each stakeholder with the other stakeholders in the network. Theoretically the judgments made by two actors should be equal. That is, if actor $I$ answered that he had contacted actor $j$, actor $j$ should then say that he has been contacted by actor $i$. Therefore, the upper diagonal of transposed matrix 1 should be equal to the lower diagonal of matrix 2 and vice versa. However the analysis of the matrices reveals that this does not always happen and indicates that two stakeholders perceived differently how often they contact each other.

This different perception may be due to failing in remembering the details of such activities as a consequence of an overload of work or, most likely, to the fact that if actor $I$ says that he has contacted actor $j$ and actor $j$ does not remember it, actor $I$ may have contacted another staff member working at entity $j$ though he does not remember exactly who.

Therefore, the first step of our proposal is to transpose matrix 1. Thus, both matrices now will represent the flow of information from rows to columns, i.e. M1 represents the viewpoint of the actors in the columns and M2 the actors in the rows. The next step consists of aggregating the information of both matrices by calculating the maximum value between transposed matrix 1and 2 for each cell. Then, 
M. García Melón, V. Estruch Guitart, P. Aragonés Beltrán, B. Monterde Roca/ Social network analysis in participatory environmental decision making

$$
\mathrm{GIM}=\max \left(\mathrm{M} 1^{\mathrm{T}}, \mathrm{M} 2\right)
$$

That is, we considered the higher flow of information from those perceived by both actors as a consequence of their different perception of the facts, as mentioned above. GIM is the resulting matrix built after aggregation.

\begin{tabular}{|l|c|l|l|l|l|l|l|l|}
\hline GIM & $\begin{array}{l}\text { Technical } \\
\text { Mngment } \\
\text { Office }\end{array}$ & $\begin{array}{l}\text { Department } \\
\text { of } \\
\text { Environmen }\end{array}$ & $\begin{array}{l}\text { Department } \\
\text { of } \\
\text { Agriculture }\end{array}$ & $\begin{array}{l}\text { Devesa- } \\
\text { Albufera } \\
\text { Service }\end{array}$ & $\begin{array}{l}\text { La Unio } \\
\text { Farmers' } \\
\text { Union }\end{array}$ & $\begin{array}{l}\text { SEO } \\
\text { Birdlife }\end{array}$ & $\begin{array}{l}\text { Fishermen's } \\
\text { Association }\end{array}$ & $\begin{array}{l}\text { Hunters } \\
\text { Society }\end{array}$ \\
\hline $\begin{array}{l}\text { Technical } \\
\text { Management Office }\end{array}$ & 0 & 1 & 0 & 1 & 0 & 1 & 1 & 1 \\
\hline $\begin{array}{l}\text { Department } \\
\text { Environment }\end{array}$ & 1 & 0 & 0 & 0 & 1 & 1 & 0 & 0 \\
\hline $\begin{array}{l}\text { Department of } \\
\text { Agriculture }\end{array}$ & 0 & 0 & 0 & 0 & 1 & 0 & 0 & 0 \\
\hline $\begin{array}{l}\text { Devesa-Albufera } \\
\text { Service }\end{array}$ & 1 & 0 & 0 & 0 & 0 & 0 & 0 & 0 \\
\hline $\begin{array}{l}\text { La Unio Farmers' } \\
\text { Union }\end{array}$ & 0 & 0 & 1 & 0 & 0 & 1 & 0 & 0 \\
\hline SEO Birdlife & 1 & 0 & 0 & 0 & 1 & 0 & 0 & 0 \\
\hline $\begin{array}{l}\text { Fishermen's } \\
\text { Association }\end{array}$ & 1 & 0 & 0 & 0 & 0 & 0 & 0 & 1 \\
\hline Hunters Society & 0 & 0 & 0 & 0 & 0 & 0 & 1 & 0 \\
\hline
\end{tabular}

Table 1. Aggregate matrix of information flow

This matrix will be used to analyze the influence of each actor in the network. It is a nonsymmetrical matrix with a directed network of actors.

\subsection{Calculation of centrality indicators for each actor}

In order to determine the degree of influence or power of the actors in a directed network each actor's centrality is measured.

UCINET@ (Borgatti, SP, 2002), a specialized software tool for the analysis of social networks, was used for the calculation of centrality

The following table shows the results of degree centrality and closeness centrality for each actor in the information network. Centrality values were normalized by their sum for further comparison.

\begin{tabular}{|l|l|l|l|l|}
\hline Stakeholders & $\begin{array}{l}\text { degree } \\
\text { Centrality }\end{array}$ & $\begin{array}{l}\text { normalized } \\
\text { degree } \\
\text { Centrality }\end{array}$ & $\begin{array}{l}\text { closeness } \\
\text { Centrality }\end{array}$ & $\begin{array}{l}\text { normalized } \\
\text { closeness } \\
\text { Centrality }\end{array}$ \\
\hline Technical Management Office of the Park & 7 & 0.175 & 100 & 0.158 \\
\hline Department of Environment & 6 & 0.15 & 87.5 & 0.138 \\
\hline Department of Agriculture & 4 & 0.1 & 70 & 0.11 \\
\hline Valencia City Council (Devesa-Albufera Service) & 6 & 0.15 & 87.5 & 0.138 \\
\hline La Unio Farmers' Union & 5 & 0.125 & 77.78 & 0.123 \\
\hline SEO Birdlife & 6 & 0.15 & 87.5 & 0.138 \\
\hline La Albufera Fishermen's Association & 4 & 0.1 & 70 & 0.11 \\
\hline Hunters Society & 2 & 0.05 & 53.84 & 0.085 \\
\hline
\end{tabular}

Table 2. Degree centrality and Closeness centrality indexes used in the Global Information Matrix 


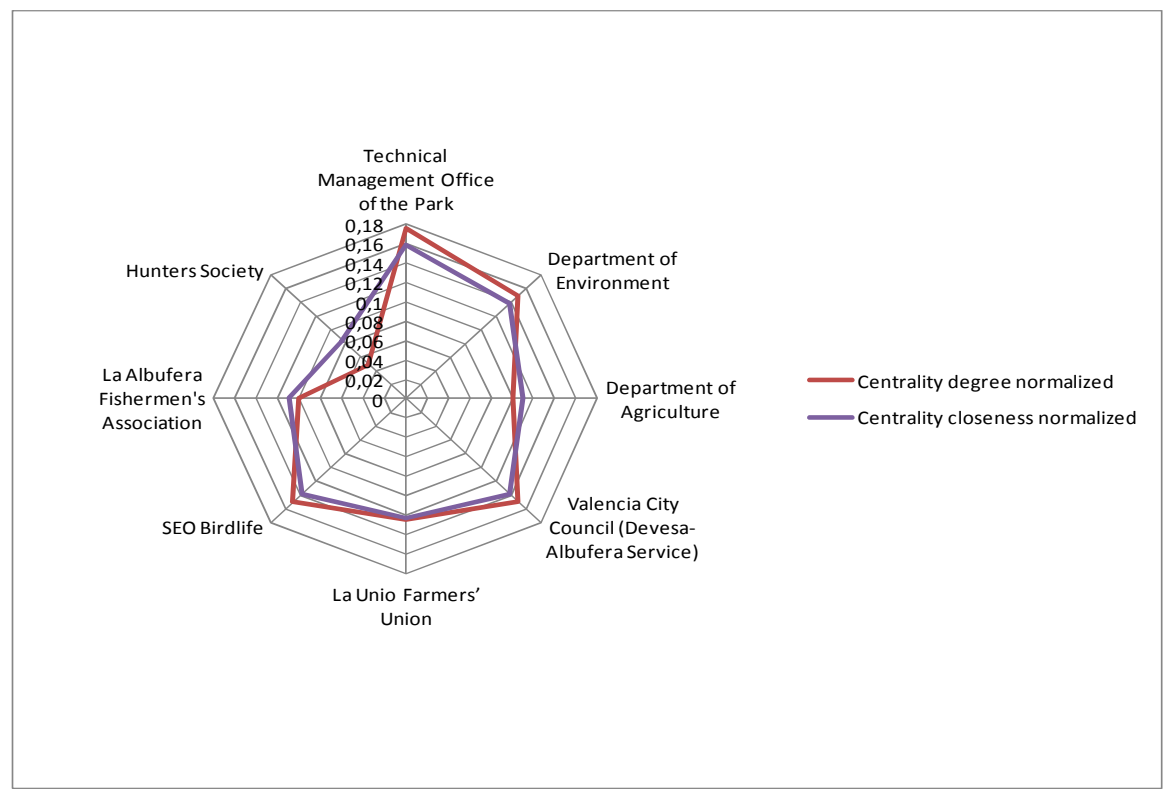

Figure 2. Degree centrality and Closeness centrality indexes used in the Global Information Matrix

According to the results of Table 2 and Figure2, degree centrality indicators show that there is one actor, the Technical Management Office of the Park, to whom all other actors ask for information. Next in importance are the Department of Environment, the SEO Birdlife NGO and Devesa-Albufera Service of the City Council of Valencia, who have contacted all other stakeholders but one. At the other end we have the hunters Society, who is contacted only by the fishermen and the Devesa-Albufera Service.

The information provided in Figure 2 also reveals that the only significant difference between the two types of centrality is found in the Hunters Society because hunters request information from both technical offices, which in turn get in contact with all the other actors, as shown by the analysis of second-order contacts.

The Centrality values of each stakeholder will be used as indicators of the relative influence of each actor on every other actor in the network.

\subsection{Modeling of the AHP problem. Selection of criteria and alternatives.}

In the case under study the decision problem is 'Rice straw management in La Albufera'. In order to identify the clusters of criteria and alternatives, we consulted the same panel of experts. First we asked about alternative straw disposal methods. We decided to study only straw management in the areas located below water level, as they are the most greatly affected by rice straw decomposition in flooded paddy fields.

The alternatives for rice straw disposal mentioned below are currently being carried out in the Natural Park of La Albufera and other paddy fields in Spain.

Following is a description of each rice straw disposal method and its environmental impacts.

A. Straw crushing and field puddling: This method consists of puddling the rice fields with disc-plough tractor to dispose of rice straw.

B. Straw burning: The purpose of straw burning is to remove organic matter (crop residues) from the soil and minimize the effects of waste decomposition in the flooded fields.

This alternative also causes serious impacts on air, health and discomfort

C. Not disposed of: Rice straw is left untreated in the rice field. 
This alternative has negative environmental impacts on the air and water as well as on the fauna and flora of the Park due to straw decomposition under anaerobic conditions Not disposing of rice straw also has harmful effects on people's health and causes bad odors.

D. Straw baling and removal from the field

The mechanical removal of rice straw from the field has proved to be technically satisfactory. However, the efficiency of the method depends on the conditions of the straw and the weather conditions at the time of baling: the straw must be entire and dry enough to allow baling; this straw disposal technique is unfeasible in early rainy years.

The problem of rice straw management is therefore an issue that generates conflicting interests. On one hand are the economic interests of the people who develop their working activity in the park and live on it. On the other are the problems that these management systems can cause to local communities living in the area as a result of the treatment of the rice straw. And finally are the environmental impacts caused on the ecosystem, such as fauna, flora, water, etc.

The criteria were grouped as follows:

- Economic criteria

- Social criteria

- Environmental criteria

We also added other nine criteria considered by the experts as necessary to properly evaluate the alternatives.

The final AHP model is as follows

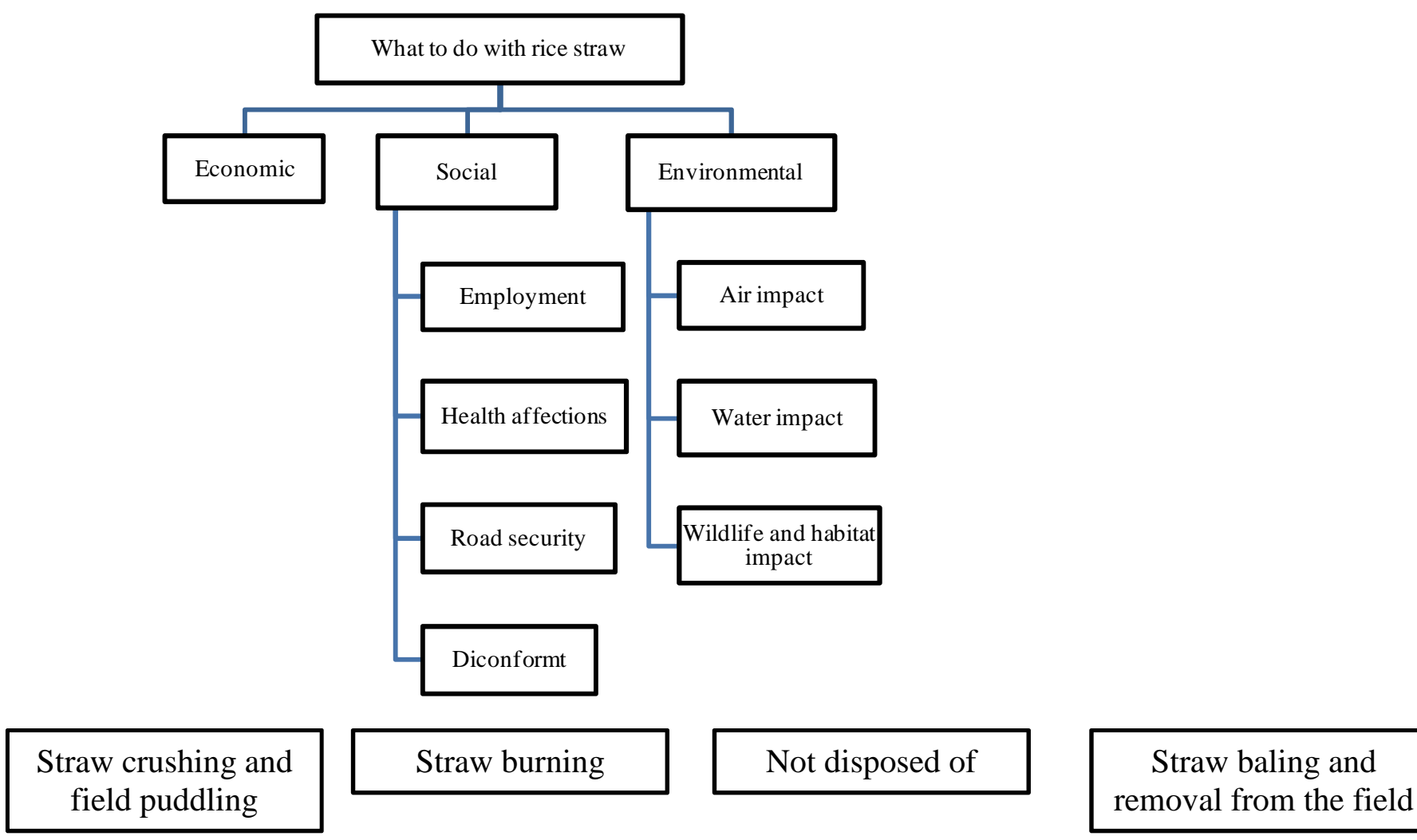

Figure 3. AHP model

The experts answered the questionnaires needed to solve the decision problem with AHP 
4.6. Solution of the participatory decision making process using AHP

After the analysis with Expert Choice (C) of the stakeholders' responses to all the pair wise questions required by the AHP model, the following results were obtained. Results were analyzed twofold: first considering that all stakeholders have the same influence in the decision making process, and second considering that each of them has a relative influence index in the network (weighted stakeholders)

$\underline{\text { Results about the criteria }}$

\begin{tabular}{|l|c|}
\hline CRITERIA & WEIGHT \\
\hline Economic & 0.083 \\
\hline Employment & 0.039 \\
\hline Health affections & 0.139 \\
\hline Road safety & 0.018 \\
\hline Discomfort & 0.034 \\
\hline Air impact & 0.112 \\
\hline Water impact & 0.25 \\
\hline $\begin{array}{l}\text { Wildlife and habitat } \\
\text { impact }\end{array}$ & 0.325 \\
\hline
\end{tabular}

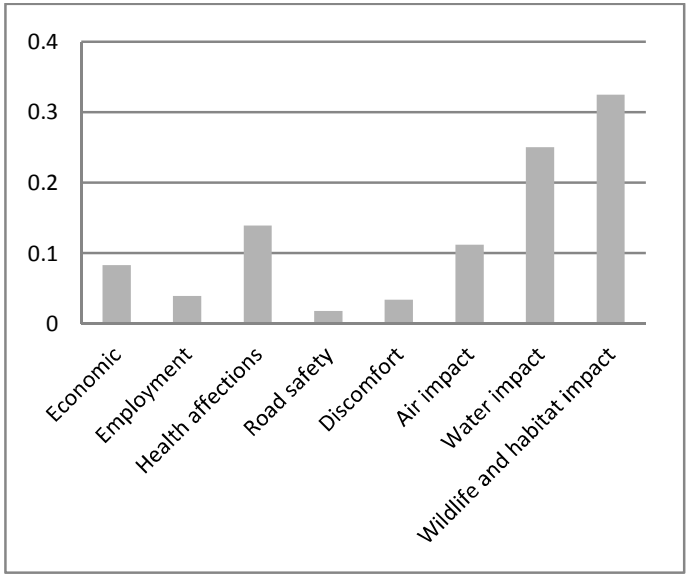

Table 3.Results for the criteria weights

Figure 4. Results for the criteria weights

$\underline{\text { Results about the alternatives }}$

\begin{tabular}{|c|c|c|c|c|c|c|c|c|c|c|c|}
\hline & & & & & & & & & & \multicolumn{2}{|c|}{ preference aggregations } \\
\hline & $\begin{array}{l}\text { VLC city } \\
\text { council }\end{array}$ & La Unió & $\begin{array}{l}\text { Management } \\
\text { Office of the }\end{array}$ & $\begin{array}{l}\text { Department of } \\
\text { Environment }\end{array}$ & $\begin{array}{l}\text { Department of } \\
\text { Agriculture }\end{array}$ & SEO/BirdLife & Hunters & Fishers & Combined & stakeholders & $\begin{array}{c}\text { weighted } \\
\text { stakeholders }\end{array}$ \\
\hline Straw crushing and field puddling & 0,272 & 0,386 & 0,295 & 0,332 & 0,234 & 0,31 & 0,08 & 0,132 & 0,242 & 0,230 & 0,255 \\
\hline Straw burning & 0,253 & 0,132 & 0,154 & 0,127 & 0,223 & 0,088 & 0,24 & 0,174 & 0,168 & 0,164 & 0,241 \\
\hline Not disposed of & 0,118 & 0,134 & 0,082 & 0,189 & 0,153 & 0,097 & 0,082 & 0,08 & 0,111 & 0,111 & 0,232 \\
\hline Straw baling and removal from fiel & 0,357 & 0,348 & 0,47 & 0,352 & 0,39 & 0,505 & 0,598 & 0,614 & 0,479 & 0,443 & 0,272 \\
\hline
\end{tabular}

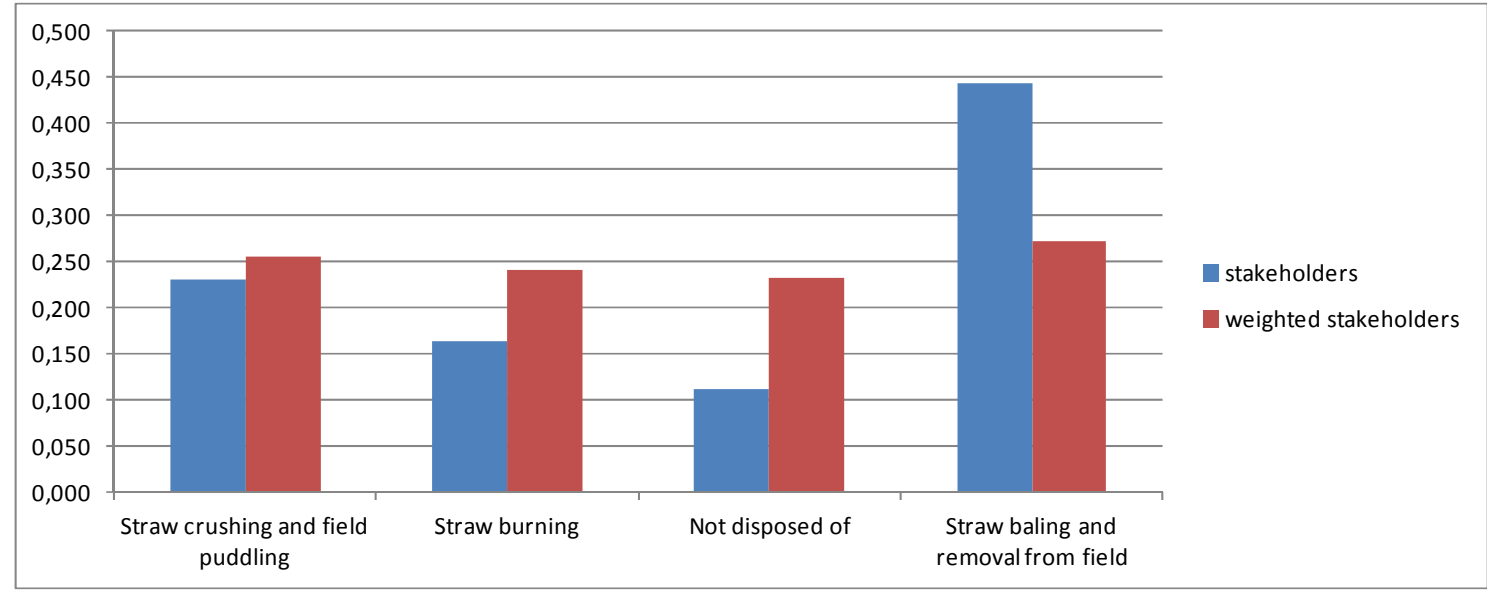

\section{Conclusions}


M. García Melón, V. Estruch Guitart, P. Aragonés Beltrán, B. Monterde Roca/ Social network analysis in participatory environmental decision making

This paper has two aims: to find out the preferred rice straw disposal method based on the results of the AHP decision-making model defined by all the stakeholders involved in the Park management; and to analyze the relative influence of the different stakeholders when making decisions using SNA analysis.

Regarding the alternatives, the preferred option is always Straw baling and removal from field, which obtains the highest score for the most important criteria as specified by the experts: Environmental criteria and health effects.

It is important to emphasize that this is by far the most preferable solution when all stakeholders are considered to have the same influence on the decision making process. However, when each stakeholder is assigned an influence index in the SNA model, the results change. The most preferred alternative considerably reduces its difference with the second best scored option, Straw crushing and field puddling.

As a general conclusion we can state that SNA is a useful tool to analyze the influence of the stakeholders in a consolidated network and that this influence does affect the final results of the decision making process. 


\section{References}

García-Melón M., Gómez-Navarro T, Acuña-Dutra S, 2012, A combined ANP-Delphi approach to evaluate sustainable tourism, Environmental Impact Assessment Review 34, 41-50

Hanneman R.A., Riddle M., 2005, Introduction to Social Network Methods, online version, file:///C//Documents\%20and\%20Settings/hanneman/My\%20...ts/Network_Text/Version2/C1_Social_Network_Data. html

Knoke, Yang, 2008, Social Network Analysis, SAGE Publications

Peris J, García-Melón M, Gómez-Navarro T, Calabuig C, 2011, Prioritizing Local Agenda 21 Programmes using Analytic Network Process: A Spanish Case Study, Sustainable Development

Reed M.S., 2008, Stakeholder participation for environmental management. A literature review, Biological Conservation, 141, 2417-2431

Regan H.M., Colyvan M., Markovchick-Nichols L, 2006, A formal model for consensus and negotiation in environmental management, Journal of Environmental Management, 80, 167-176

Sedereviciute K., Valentini, C., 2011, Towards a More Holistic Stakeholder Analysis Approach. Mapping Known and Undiscovered Stakeholders from Social Media, International Journal of Strategic Communication, Volume 5, Issue 4

Wasserman, S. and F. Faust., 1994., Social network analysis: Methods and applications.

Cambridge, MA: Cambridge University Press. 